\title{
Effect of Soil and Foliar Application of Micronutrients Mixture on Growth and Yield of Blackgram
}

\author{
K. S. Divyashree*, S. S. Prakash, S. B. Yogananda, P. K. Basavaraja, \\ T. C. Chamegowda and P. Mahadevu \\ Department of Soil Science and Agricultural Chemistry, College of Agriculture, \\ GKVK, UAS, Bengaluru, India \\ *Corresponding author
}

\section{A B S T R A C T}

\section{Keywords}

Soil and foliar application of micronutrients mixture

Article Info

Accepted:

15 December 2019

Available Online:

20 January 2020
Field experiment was conducted during early kharif2017 at College of Agriculture, V.C. Farm, Mandya to study the effect of soil and foliar application of micronutrients mixture on growth and yield of blackgram. Experiment was laid out in RCBD with fourteen treatments including control, RDF + FYM, foliar application of MM at 20 DAS (MMF1 and MMF2), 40 DAS (MMF1 and MMF2) along with RDF+FYM, Foliar spray at 20 and 40 DAS along with FYM+RDF and soil application of MMS1, MMS2, MMS3 and MMS4 along with RDF+FYM. These treatments were replicated thrice. Micronutreints mixture comprising $\mathrm{Fe}(20.10 \mathrm{~g}), \mathrm{Mn}(18.20 \mathrm{~g}), \mathrm{Zn}(160 \mathrm{~g}), \mathrm{Cu}(12.73 \mathrm{~g})$, with $\mathrm{B}(43.70$ $\mathrm{g}) /$ without $\mathrm{B}, \mathrm{Mo}(2.33 \mathrm{~g})$ was prepared using appropriate micronutrients salts for foliar application per acre and $\mathrm{Fe}(80.4 \mathrm{~g}), \mathrm{Mn}(72.8 \mathrm{~g}), \mathrm{Zn}(640 \mathrm{~g}), \mathrm{Cu}(50.92 \mathrm{~g})$, with $\mathrm{B}(174.8$ $\mathrm{g}) /$ without B, Mo(9.32 g) for MMS1 and two, three and four times that of MMS1 for other mixture (MMS2, MMS3 and MMS4, respectively) per acre for soil application. Results revealed that foliar application of MMF1 at 20 days after sowing and MMF2 at 40 days after sowing along + RDF+FYM recorded significantly higher plant height $(51.17 \mathrm{~cm})$, number of leaves per plant (14.07 )number of branches per plant (14.37),number of pods per plant (58.50), number of seeds per pod (7.47)and seed yield ( $\left.1655.54 \mathrm{~kg} \mathrm{ha}^{-1}\right)$ and dry matter $\left.\left(19.87 \mathrm{~g} \mathrm{plant}^{-1}\right)\right)$ of blackgram. While higher haulm yield $\left(2424.61 \mathrm{~kg} \mathrm{ha}^{-1}\right)$ and was observed with MMS2 + RDF+FYM. The increase in yield and growth parameters was attributed to micronutrients nutrition through foliage.

\section{Introduction}

Pulses play a vital role in human and animal nutrition as these provide proteins, minerals, vitamins. In India pulses cover an area of about 23.47 million hectares with an annual production of 19.78 million tonnes and a productivity of $785 \mathrm{~kg} \mathrm{ha}^{-1}$ (GOI, 2013-14). Blackgram [Vigna mungo (L.) Hepper] is one of the most important pulse crops of rainfed areas grown throughout the country. This crop is grown in different cropping system as a mixed crop, catch crop, sequential crop in the country. Blackgram seed contains 25-26\% 
proteins, $60 \%$ carbohydrates, $1.5 \%$ fat, and minerals, amino acid, and essential vitamins etc. In India black gram is grown in Andhra Pradesh, Bihar, Madhya Pradesh, Maharashtra, U.P., West Bengal, Punjab, Haryana, and Karnataka. It is used as nutritive fodder especially for milch cattle.

However, like most pulses blackgram grown on marginal lands, under limited moisture regimes (rainfed areas) and low fertile soil leading to lower productivity of this crop. Inadequate and imbalanced nutrient application is also contributing factor for low productivity. To increase or to sustain the productivity of blackgram, there is a need for application of micronutrients along with the major nutrients mainly because of practice of intensive cropping with high yielding varieties for boosting food production caused nutrient depletion in soil, consequently macro and micronutrients deficiencies in soils.

Micronutrients have a specific role in leguminous crops like $\mathrm{N}_{2}$ fixation by root nodule bacteria, meristematic activity, maintaining correct water relations within the plant and sugar translocation and activator as a co-factor in several enzyme activities. Use of micronutrients like $\mathrm{Fe}, \mathrm{Mn}, \mathrm{Zn}, \mathrm{Cu}, \mathrm{B}$ and $\mathrm{Mo}$ can increase the productivity of the crop. However, little work has been done on this aspect in blackgram. Therefore, an experiment was conducted to study the effect of micronutrients mixture along with NPK fertilizers on growth, yield and micronutrient content in blackgram.

\section{Materials and Methods}

Field experiment was conducted during early Kharif 2017 on sandy loam soil at College of Agriculture, V.C. Farm, Mandya, University of Agricultural Sciences, Bengaluru, Karnataka to study the effect of micronutrients mixture application on growth and yield of blackgram in Southern Dry Zone (Zone 6) of
Karnataka. The experiment was laid out in RCBD with fourteen treatments including control, RDF + FYM, foliar application of MMF1 and MMF2 at 20 DAS, MMF1 and MMF2 at 40 DAS along with RDF+FYM and their combinations and soil application of MMS1,MMS2, MMS3 and MMS4 along with RDF+FYM.Initial soil properties of the experimental site during 2017 was presented in the Table 1.

Recommended dose of NPK (12.5:25:25 kg $\mathrm{ha}^{-1}$ ) for blackgram was supplied with urea, single super phosphate and murate of potash, respectively and micronutrient mixture (MMS1 and MMS2) comprising Fe, Mn, Zn, $\mathrm{Cu}, \mathrm{B}$ and $\mathrm{Mo}$ (Table 2) was applied at the time of sowing in the form of iron sulphate, manganese sulphate, zinc sulphate, copper sulphate, borax and sodium molybdate, respectively. Micronutrient mixture containing the amount as indicated in Table 2 for foliar spray was prepared by dissolving the appropriate quantity of all the micronutrient salts in distilled water.

Then the $\mathrm{pH}$ of the solution was adjusted to 6.5 using $1 \% \mathrm{KOH}$ solution. This solution was used for foliar spraying (@ 500 1/ha) at 20 and 40 DAS as per the treatment plan. Crop was harvested at proper maturity. Periodical and quantitative observations were taken in order to assess the effect of micronutrients mixture ongrowth, yield and yield parameters.Mature pods were harvested manually by hand picking. The grain was separated by manual threshing. Grain and haulm yield was recorded separately treatment wise.

\section{Results and Discussion}

The data presented in the table 3 indicated that application of micronutrients mixture on growth parameters of blackgram was significant. The plant height in control treatment was $33.93 \mathrm{~cm}$ and it was increased to 51.17 and $44.05 \mathrm{~cm}$ significantly due to 
application of RDF + FYM + MMS1 at 20 DAS and MMF2 at 40 DAS and RDF + FYM + MMS2 application. Significantly highest number of leaves were recorded in $\mathrm{T}_{7}$ treatment and on par with $\mathrm{T}_{8}, \mathrm{~T}_{9}, \mathrm{~T}_{10}, \mathrm{~T}_{11}$ and $\mathrm{T}_{12}$.Significantly Maximum number of branches were recorded in $\mathrm{T}_{7}$ (14.37) and it was on par with $T_{9}$ (14.07) and lowest was recorded in control (7.63). Dry matter production per plant was increased to $\mathrm{T}_{7}$ $(19.87 \mathrm{~g})$ significantly followed by RDF + FYM + MMS2 (18.91g).

Table.1 Initial Physico-chemical properties of the soils.

\begin{tabular}{|c|c|c|}
\hline SI. No & Parameter & Site 1 (2017) \\
\hline \multicolumn{3}{|c|}{ I.Physical properties } \\
\hline & Coarse sand (\%) & 55.70 \\
\hline & Fine sand $(\%)$ & 25.87 \\
\hline & Silt (\%) & 14.9 \\
\hline & Clay (\%) & 3.53 \\
\hline & Textural Class & Sandy loam \\
\hline \multicolumn{3}{|c|}{ II.Chemical properties } \\
\hline 1 & $\mathrm{pH}(1: 2.5)$ & 7.39 \\
\hline 2 & $\mathrm{EC}\left(\mathrm{dS} \mathrm{m^{-1 } )}\right.$ & 0.13 \\
\hline 3 & Organic carbon $\left(\mathrm{g} \mathrm{kg}^{-1}\right)$ & 1.53 \\
\hline 4 & Available $\mathrm{N}\left(\mathrm{kg} \mathrm{ha}^{-1}\right)$ & 252.97 \\
\hline 5 & Avail. $\mathrm{P}_{2} \mathrm{O}_{5}\left(\mathrm{~kg} \mathrm{ha}^{-1}\right)$ & 45.8 \\
\hline 6 & Avail. $\mathrm{K}_{2} \mathrm{O}\left(\mathrm{kg} \mathrm{ha}^{-1}\right)$ & 345.96 \\
\hline 7 & Exch. Ca $\left(\mathrm{cmol} \mathrm{ha}^{-1}\right)$ & 3.24 \\
\hline 8 & Exch.Mg $\left(\mathrm{cmol} \mathrm{ha}^{-1}\right)$ & 1.89 \\
\hline 9 & Available $\mathrm{S}\left(\mathrm{mg} \mathrm{kg}^{-1}\right)$ & 15.67 \\
\hline 10 & DTPA Fe $\left(\mathrm{mg} \mathrm{kg}^{-1}\right)$ & 17.82 \\
\hline 11 & DTPA Zn (mg kg $\left.{ }^{-1}\right)$ & 0.52 \\
\hline 12 & DTPA Mn $\left(\mathrm{mg} \mathrm{kg}^{-1}\right)$ & 8.78 \\
\hline 13 & DTPA Cu $\left(\mathrm{mg} \mathrm{kg}^{-1}\right)$ & 0.53 \\
\hline 14 & Hot water soluble Boron $\left(\mathrm{mg} \mathrm{kg}^{-1}\right)$ & 0.46 \\
\hline
\end{tabular}

Table. 2 Micronutrient carrier and content of micronutrient in the mixture used in different crops

\begin{tabular}{|c|c|c|c|c|c|c|c|}
\hline $\begin{array}{c}\text { Micronutrients salts } \\
\text { used }\end{array}$ & Form & $\begin{array}{l}\text { MMF1 } \\
\left(\mathrm{g} \mathrm{ha}^{-1}\right)\end{array}$ & $\begin{array}{l}\text { MMF2 } \\
\left(\mathrm{g} \mathrm{ha}^{-1}\right)\end{array}$ & $\begin{array}{l}\text { MMS1 } \\
\left(\mathrm{g} \mathrm{ha}^{-1}\right)\end{array}$ & $\begin{array}{l}\text { MMS2 } \\
\left(\mathrm{g} \mathrm{ha}^{-1}\right)\end{array}$ & $\begin{array}{l}\text { MMS3 } \\
\left(\mathrm{g} \mathrm{ha}^{-1}\right)\end{array}$ & $\begin{array}{l}\text { MMS4 } \\
\left(\mathrm{g} \mathrm{ha}^{-1}\right)\end{array}$ \\
\hline $\mathrm{Fe}_{2} \mathrm{SO}_{4} \cdot 7 \mathrm{H}_{2} \mathrm{O}$ & $\mathrm{Fe}$ & 50.25 & 50.25 & 100.5 & 201 & 100.5 & 201 \\
\hline $\mathrm{MnSO}_{4} \cdot 5 \mathrm{H}_{2} \mathrm{O}$ & Mn & 45.5 & 45.5 & 91 & 182 & 91 & 182 \\
\hline $\mathrm{ZnSO}_{4} \cdot 7 \mathrm{H}_{2} \mathrm{O}$ & $\mathrm{Zn}$ & 400 & 400 & 800 & 1600 & 800 & 1600 \\
\hline $\mathrm{CuSO}_{4} .7 \mathrm{H}_{2} \mathrm{O}$ & $\mathrm{Cu}$ & 31.82 & 31.82 & 63.64 & 127.28 & 63.64 & 127.28 \\
\hline Sodium molybdate & Mo & 5.82 & 5.82 & 11.64 & 23.28 & 11.64 & 23.28 \\
\hline Boric acid & B & - & 109.25 & 218.5 & 437 & - & - \\
\hline
\end{tabular}

*MMS-micronutrients mixture for soil application, MMF-micronutrients mixture for foliar application 
Table.3 Effect of micronutrients mixture application on growth parameters

\begin{tabular}{|l|c|c|c|c|}
\hline Treatments & $\begin{array}{c}\text { Plant height } \\
\text { (cm) }\end{array}$ & $\begin{array}{c}\text { Number of leaves per } \\
\text { plant }\end{array}$ & $\begin{array}{c}\text { Number of } \\
\text { branches per } \\
\text { plant }\end{array}$ & $\begin{array}{c}\text { Dry matter } \\
\text { production per } \\
\text { plant }(\mathbf{g} \text { plant }\end{array}$ \\
\hline $\mathbf{T}_{\mathbf{1}}$ )
\end{tabular}

Table.4 Effect of micronutrients mixture application on yield attributes and yield of black gram

\begin{tabular}{|c|c|c|c|c|c|c|}
\hline Treatments & $\begin{array}{l}\text { Pod length } \\
\text { (cm) }\end{array}$ & $\begin{array}{c}\text { Number of } \\
\text { pods per plant }\end{array}$ & $\begin{array}{c}\text { Number of } \\
\text { seeds per pod }\end{array}$ & $\begin{array}{l}\text { Test } \\
\text { weight } \\
\text { (g) }\end{array}$ & $\begin{array}{l}\text { Seed } \\
\text { yield }(\mathrm{kg} \\
\left.\mathrm{ha}^{-1}\right)\end{array}$ & $\begin{array}{l}\text { Haulm yield } \\
\left(\mathrm{kg} \mathrm{ha}^{-1}\right)\end{array}$ \\
\hline $\mathbf{T}_{1}$ & 5.40 & 25.08 & 5.69 & 4.55 & 947.76 & 1125.27 \\
\hline $\mathbf{T}_{2}$ & 5.72 & 44.75 & 7.44 & 4.66 & 1070.49 & 1355.16 \\
\hline $\mathbf{T}_{\mathbf{3}}$ & 6.09 & 48.25 & 7.01 & 5.15 & 1157.77 & 1870.43 \\
\hline $\mathbf{T}_{4}$ & 6.25 & 47.25 & 6.68 & 4.96 & 1233.70 & 1769.44 \\
\hline $\mathbf{T}_{5}$ & 5.59 & 48.75 & 7.21 & 5.35 & 1077.07 & 1655.95 \\
\hline$T_{6}$ & 5.97 & 54.08 & 7.47 & 5.29 & 1619.64 & 1805.75 \\
\hline $\mathbf{T}_{7}$ & 6.62 & 58.50 & 7.92 & 5.41 & 1655.54 & 2358.82 \\
\hline $\mathbf{T}_{8}$ & 6.39 & 48.25 & 7.37 & 5.21 & 1170.78 & 1928.03 \\
\hline $\mathbf{T}_{9}$ & 6.05 & 52.33 & 7.38 & 4.99 & 1424.60 & 2147.71 \\
\hline$T_{10}$ & 5.70 & 51.08 & 6.87 & 4.49 & 1268.14 & 2036.74 \\
\hline$T_{11}$ & 6.55 & 46.92 & 6.96 & 4.59 & 1114.03 & 2279.89 \\
\hline$T_{12}$ & 5.71 & 50.17 & 7.67 & 5.07 & 1250.22 & 2424.61 \\
\hline$T_{13}$ & 6.24 & 49.67 & 7.15 & 5.17 & 924.44 & 2054.68 \\
\hline$T_{14}$ & 6.01 & 48.08 & 6.51 & 5.09 & 1050.62 & 2270.93 \\
\hline SEm \pm & 0.27 & 2.43 & 0.35 & 0.22 & 56.66 & 84.24 \\
\hline $\mathrm{CD}(\mathrm{p}=\mathbf{0 . 0 5})$ & 0.81 & 7.07 & 1.01 & NS & 164.72 & 244.90 \\
\hline
\end{tabular}


The increase in growth parameters with supplementation of micronutrients mixture might be attributed to the balanced nutrition of the crop. Also, the addition of the micronutrients helps in better utilization of the major nutrients to produce higher biomass production. The hidden deficiencies of micronutrients are overcome due to their supplementation during the growth period, which results in better crop growth. The beneficial effect on use of micronutrients mixture have been reported in different crops for good growth; Blackgram (Kannan et al., 2014, Poongothai and Chitdeshwari, 2003, cowpea (Hemn, 2013), chickpea (Valenciano et al., 2010) and mungbean (Quddus et al., 2011).

Effect of micronutrients mixture application on yield attributes and yields of blackgram

Application of micronutrients mixture have significant effect on yield and yield attributes of blackgram except test weight represented in Table 4. Significantly higher pod length $(6.62 \mathrm{~cm})$ was observed with the application of RDF + FYM+ MMF1 at 20 DAS+ MMF2 at 40 DAS followed by RDF + FYM +MMS1 over control, RDF+ FYM, $T_{5}, \mathrm{~T}_{10}$ and $\mathrm{T}_{12 .}$.Smilar trend also observed in the number of pods per plant and number of seeds per pod. Significantly higher seed yield was observed in $\mathrm{T}_{7}\left(1655.54 \mathrm{~kg} \mathrm{ha}^{-1}\right)$ over control and RDF+ FYM followed by $\mathrm{T}_{6}$ (RDF+ FYM+ MMF2 at 40 DAS).Significantly higher haulm yield was observed in $T_{12}$ $\left(2279.89 \mathrm{~kg} \mathrm{ha}^{-1}\right)$ and it was on par with other treatments with the soil application of micronutrients mixture along with RDF+FYM.

Application of (Fe, Mn, Cu, Zn, B and Mo) maintained early crop vigour and growth, dry matter production by augmenting photosynthetic process and higher production of photosynthatase as some of these acts as co-factor in enzyme involved in electron transport process of photosynthesis and respiration and in chloroplast synthesis, which might have helped in better yield attributes, seed and haulm yield (Hazraet al., 1987). Poongothai and Chitdeshwari, 2003 have reported that combined foliar application of $\mathrm{Zn}, \mathrm{B}$ and Mo recorded higher yield of blackgram compared to their individual application.

The results indicated that soil or foliar application of micronutrients mixture along with $\mathrm{RDF}+\mathrm{FYM}$ can significantly enhance the growth, yield and nutrient content of blackgram. Application of micronutrients mixture ensures the balanced supply of nutrients which in turn helps in improving the nutritional quality of crops.

\section{Acknowledgement}

Department of science and Technology, Ministry of Science and Technology Government of India for awarding INSPIRE fellowship to carry out the research as part of Doctoral Degree program of corresponding author.

\section{References}

Goi. 2013.Submitted by Zonal Project Directorate Kanpur, pp.20- 35 Gupta, A., Sharma, V.K., Sharma, G.D. and Chopra, P. 2006. Effect of biofertilizers and phosphorus levels on yield attributes, yield and quality of urbdean (Vigna mungo).Indian J. Agronomy.51(2):142-144.

Hazra, P., Maity, T.K. and Mandal, A.R., 1987, Effect of foliar application of micronutrients on growth and yield of okra (Abelmoschus esculentus L). Prog. Hort., 19: 219-222. 
Hemn. O. S., 2013, Effect of Foliar Fertilization of $\mathrm{Fe}, \mathrm{B}$ and $\mathrm{Zn}$ on nutrient concentration and seed protein of Cowpea "Vigna Unguiculata". J. Agri. Vet. Sci., (6): 42-46.

Kannan, P., Arunachalam, P., Prabukumar, G., and Prabhaharan, J., 2014, Response of Blackgram(Vigna Mungo L.) to multi micronutrients mixtures under Rainfed Alfisol. J. Indian Soc. Soil Sci., 62(2): 154-160.

Kumawat, R.N., Rathore, P.S. and Pareek, N., 2006, Response of mungbean to sulphur and iron nutrition grown on calcareous soil of Western Rajasthan.Indian $J$. Pulse Res., 19:228-230.

Poongothai, S. and Chitdeshwari, T., 2003, Response of blackgram to multi micronutrients mixture. Madras Agric. J., 90(7-9): 442-443.
Quddus, M.A., Rashid, M.H., Hossain, M.A., and Naser, H.M.,2011, Effect of zinc and boron on yield and yield contributing characters of mungbean in low ganges river floodplain soil at Madaripur. Bangladesh. Bangladesh J. Agril. Res., 36(1): 75-85

Tripathi, H.C., SINGH, R.S. AND MISHRA, V.K., 1997, Effect of S and Zn nutrition on Yield and quality of chick pea (Cicer arietinum L.). J. Indian Soc. Soil Sci., 45: $123-126$

Valenciano, J. B., Boto, J.A. and Marcelo, V., 2010, Response of chickpea (Cicer arietinum L.) Yield to zinc, boron and molybdenum application under pot conditions. Spanish J. Agril. Res., 8(3):797-807.

\section{How to cite this article:}

Divyashree. K.S., Prakash. S.S., Yogananda, S.B., Basavaraja. P.K., Chamegowda, T.C. and Mahadevu. P. 2020. Effect of Soil and Foliar Application of Micronutrients Mixture on Growth and Yield of Blackgram. Int.J.Curr.Microbiol.App.Sci. 9(01): 1490-1495.

doi: https://doi.org/10.20546/ijcmas.2020.901.166 